\title{
Pengembangan Game Tradisional Megala-gala Berbasis Android
}

\author{
I Gede Edy Antara ${ }^{1}$, I Made Putrama ${ }^{2}$, I Gede Partha Sindu ${ }^{3}$ \\ Program Studi Pendidikan Teknik Informatika \\ JurusanTeknik Informatika \\ Fakultas Teknik dan Kejuruan \\ Universitas Pendidikan Ganesha \\ Email : edyb4n4t@gmail.com¹, made.putrama@undiksha.ac.id²,partha.sindu@undiksha.ac.id ${ }^{3}$
}

\begin{abstract}
Abstrak-Penelitian ini bertujuan untuk mengimplementasikan game tradisional megala-gala berbasis android dan mengetahui bagaimana hasil dari respon pengguna dalam implementasinya. Pengembangan game tradisional megala-gala menggunakan metode GDLC (Game Development Life Cycle) yang terdiri dari initiation, preproduction, production, testing, beta dan relesase dengan berlandaskan atas lenses theory agar hasil game yang dibuat menjadi baik. Hasil penelitian ini menunjukkan respon yaitu untuk uji kasus 1 : penggunaan aplikasi pada perangkat android yang berbeda mendapatkan rata-rata hasil $86 \%$, dimana terdapat ketidaksesuaikan tampilan pada perangkat yang memiliki ratio layar 18:9 dan 19:9. Uji kasus 2 : kebenaran proses aplikasi mendapatkan rata-rata hasil $100 \%$, artinya aplikasi sudah berjalan dengan sangat baik sesuai fungsinya. Uji kasus 3 : tampilan, kualitas teknis dan leveling mendapatkan rata-rata hasil $90 \%$ yang artinya aplikasi sudah kategori sangat baik. Uji kasus 4 : kelayakan aplikasi sebagai game tradisional, mendapatkan hasil rata-rata nilai $100 \%$ yang artinya game ini layak sebagai media pengenalan dan pelestari permainan tradisional megala-gala.
\end{abstract}

Kata Kunci : Permainan Tradisional, Megala-gala, GDLC, Game Development Life Cycle, Lenses Theory.

Abstract-This research aims to implement the megala-gala traditional game based on android and find out how the results of user responses in its implementation. Development of megala-gala traditional games using the GDLC (Game Development Life Cycle) method which consists of initiation, pre-production, production, testing, beta and release based on lenses theory so that the game results are to be a better. The results of this research indicate a response that is to test case 1: the use of applications on different android devices gets an average yield of $86 \%$, where there is a mismatch of appearance on the device that has a screen ratio of 18:9 and 19:9. Test case 2: the truth of the application process gets an average yield of $100 \%$, meaning that the application has run very well according to its function. Test case 3: appearance, technical quality and leveling get an average yield of $90 \%$ which means that the application has been in a very good category. Test case 4: the app feasibility as a traditional game, get an average yield of $100 \%$, which means this game is feasible as a medium for the introduction and preservation of megala-gala traditional games.

\section{Keywords: Traditional Game, Megala-gala, GDLC (Game Development Life Cycle), Lenses Theory.}

\section{PENDAHULUAN}

Indonesia adalah sebuah negara yang kaya akan keunikan suku dan budaya. Tiap-tiap daerah di Indonesia memiliki ciri khas kebudayaan berbeda satu sama lainnya. Menurut Widyosismoyo [1], bahwa kebudayaan berarti keseluruhan gagasan dan karya manusia yang harus dibiasakan dengan belajar serta keseluruhan dari hasil budi pekertinya. Salah satu contoh kebudayaan adalah permainan tradisional. Indonesia memiliki keanekaragaman permainan tradisional, setiap daerah di Indonesia memiliki permainan tradisional yang menjadi ciri khas dari daerah asalnya. Seperti di daerah Bali yang memiliki berbagai permainan tradisional yang menarik dan unik.

Di tengah zaman yang semakin modern, keberadaan permainan tradisional semakin tak dilirik. Permainan tradisional sangat jarang kita temukan di desa apalagi di daerah perkotaan. Anak-anak modern juga umumnya lebih menyukai bermain game komputer atau playstation dibandingkan dengan bermain permainan tradisional. Beberapa orang tua juga tidak berinisiatif untuk mengenalkan permainan tradisional kepada anak-anaknya. Realita itu Menurut I Made Taro [2] dapat mengantarkan permainan yang memiliki banyak manfaat ini terancam punah. Dihadapkan dengan kondisi demikian, langkah untuk melakukan pelestarian wajib dilakukan.

Salah satu permainan tradisional rakyat Bali yang memiliki nilai budaya dan nilai moral yang mulai terlupakan adalah Megala-gala. Jenis permainan ini memerlukan ketangkasan untuk menghindar serta menyerang. Menghindar maksudnya ialah menghindarkan bagian-bagian tubuh yang diserang. Sedangkan menyerang memiliki arti mencari bagian tubuh lawan untuk ditepuk atau diraba sehingga lawan mati atau kalah. Dalam pertandingan dua kelompok tersebut akan 
nyata terlihat bagaimana mereka memupuk kerja sama sehingga terasa fanatisme kelompok sangat menonjol. Namun tetap dilandasi oleh sportivitas bertanding yang tinggi.

Pengembangan sejenis juga pernah dikembangkan oleh Kemal Farouq Mauladi pada tahun 2016 dengan judul Game Gobak Sodor Berbasis Android, dikembangkan menggunakan App Adobe Flash CS6 yang berhasil berjalan tanpa error [3]. Pengembangan lain juga dilakukan oleh Bella Dwi Cahya Putri pada tahun 2016 yang berjudul Perancangan Aplikasi Permainan Multiplayer Gobak Sodor Berbasis Flash di Lingkup Jaringan Lokal. Aplikasi diuji dengan metode blackbox mendapat hasil bahwa masih terdapat bug pada permainan bersama [4]. Pada jurusan Pendidikan Teknik Informatika, Universitas Pendidikan Ganesha juga pernah dilakukan pengembangan game pada tahun 2015 oleh I Gede Wija Antara yang berjudul Pengembangan Game Jegog Berbasis Android. Pengembangan game ini menggunakan metode siklus hidup pengembangan perangkat lunak dalam bentuk sekuensial linier atau model air terjun [5] dan pengembangan lain juga dikembangkan oleh I Kadek Dede Permana pada tahun 2015 yang berjudul Pengembangan Game Edukasi Siap Selem Berbasis Android. Pengembangan game ini menggunakan metode SDLC dalam bentuk sekuensial linier atau model air terjun [6]. Merujuk pada pengembangan sejenis yang digunakan refrensi tersebut masih belum terdapat teori yang berkaitan dengan proses pembuatan game yang sesuai dengan apa yang direncanakan. Desain permainan merupakan suatu proses. Proses yang dimaksud adalah sebuah proses artistik, tetapi juga bisa disebut dengan sebuah proses teknis. Teori permainan merupakan sebuah petunjuk untuk memberikan kontribusi teoritis yang baik terhadap pemain [7]. Menurut Schell [8] dijelaskan bahwa ada 113 lensa teori (Lenses Theory) dalam desain game yang nantinya digunakan acuan dalam perancangan pembuatan game.

Berlandaskan dari permasalahan diatas, maka sangat penting dikembangkan suatu game yang memadukan antara teknologi dan permainan tradisional dengan berlandaskan pada lenses theory. Salah satu permainan tradisional yang akan dikembangkan adalah megala-gala dengan berbasis sistem android. Aplikasi mobile yang dibuat adalah Aplikasi Game Tradisional "megala-gala" berbasis android yang dapat menjadi alternatif dan dapat meningkatkan pengetahuan tentang permainan tradisional yang mudah dipahami dan menarik. Diharapkan dari pengembangan game tradisional "megala-gala" berbasis android ini dapat menjadi sarana alternatif pengenalan permainan tradisional serta nilai-nilai yang terkandung dalam permainan tradisional "megala-gala"..

\section{KAJIAN PUSTAKA}

\section{A. Kajian Pustaka}

Penelitian pengembangan game tradisional Megalagala merujuk pada beberapa hasil penelitian terkait. Peneliti mendapat ide dan wawasan yang didukung dari beberapa jurnal yang telah diterbitkan sebelumnya dari berbagai sumber. Adapun jurnal-jurnal yang mendukung dalam penulisan penelitian ini adalah sebagai berikut :

Pengembangan yang pernah dikembangkan oleh Kemal Farouq Mauladi pada tahun 2016 dengan judul Game Gobak Sodor Berbasis Android[3].Pengembangan lain juga dilakukan oleh Bella Dwi Cahya Putri pada tahun 2016 yang berjudul Perancangan Aplikasi Permainan Multiplayer Gobak Sodor Berbasis Flash di Lingkup Jaringan Lokal[4].Pada jurusan Pendidikan Teknik Informatika, Universitas Pendidikan Ganesha juga pernah dilakukan pengembangan game pada tahun 2015 oleh I Gede Wija Antara yang berjudul Pengembangan Game Jegog Berbasis Android[5].Pada jurusan Pendidikan Teknik Informatika, Universitas Pendidikan Ganesha juga pernah dilakukan pengembangan game pada tahun 2015 oleh I Kadek Dede Permana yang berjudul Pengembangan Game Edukasi Siap Selem Berbasis Android.[6].

Merujuk pada pengembangan sejenis yang digunakan refrensi tersebut masih belum terdapat teori yang berkaitan dengan proses pembuatan game yang sesuai dengan apa yang direncanakan. Desain permainan merupakan suatu proses. Proses yang dimaksud adalah sebuah proses artistik, tetapi juga bisa disebut dengan sebuah proses teknis. Selama proses mengembangkan, permainan menghuni dua dunia yang sangat berbeda yakni dunia artistik dan teknis. Permainan harus memiliki tujuan yang jelas. Tujuan ini harus dinyatakan dalam efek yang akan di memiliki pada setiap pemain. Teori permainan merupakan sebuah petunjuk untuk memberikan kontribusi teoritis yang baik terhadap pemain[7]. Menurut Schell[8] dijelaskan bahwa ada 113 lensa teori (Lenses Theory) dalam desain game yang nantinya digunakan acuan dalam perancangan pembuatan game. Rancangan game yang baik adalah rancangan yang dapat dilihat dari berbagai sudut pandang, lenses theory merupakan kumpulan berbagai pertanyaan yang harus diajukan kepada diri pengguna sendiri sebelum merancang game, terdapat beberapa lenses theory, dimana tiap lenses memiliki tujuan dan fungsinya masingmasing. Dengan menggabungkan beberapa lenses theory yang sesuai, maka dengan mudah dapat merancang suatu game dengan baik.

\section{B. LandasanTeori}

a. Permainan Tradisional

Permainan tradisional telah lahir sejak ribuan tahun yang lalu, hasil dari proses kebudayaan manusia zaman dahulu yang masih kental dengan nilai-nilai kearifan lokal. Meskipun sudah sangat tua, ternyata permainan tradisional memiliki peran edukasi yang sangat manusiawi bagi proses belajar seorang individu, terutama anak-anak. Dikatakan demikian, karena secara alamiah permainan tradisional mampu menstimulasi berbagai aspek-aspek perkembangan anak yaitu: motorik, kognitif, emosi, bahasa dan sosial[9].

\section{b. Megala-gala}


ISSN 2252-9063

Kumpulan Artikel Mahasiswa Pendidikan Teknik Informatika

(KARMAPATI)

Megala-gala diambil dari kata Bali "gala 'yang berarti rintangan. Permainan tradisional ini bisa dimainkan oleh anakanak atau orang dewasa. Megala-gala adalah permainan rintangan dan terdiri dari dua tim, satu bertindak sebagai team penyerang dan yang lainnya sebagai team penjaga yang mencegah para penyerang. Setiap kelompok terdiri dari 3 atau 5 peserta tergantung besar dan model lintasan yang digunakan[10].

Permainan ini biasanya dilakukan oleh dua kelompok anak yang telah mendapat kesepakatan bahwa kekuatan mereka seimbang. Seimbang dalam jumlah pemain maupun seimbang dalam hal kekuatan. Sebab seorang anak yang benar-benar tangguh mungkin nilai kekuatan atau ketangkasannya baru seimbang bila dibandingkan dengan dua hingga tiga orang anak lainnya.

Dalam pertandingan dua kelompok tersebut akan nyata terlihat bagaimana mereka memupuk kerja sama sehingga terasa fanatisme kelompok sangat menonjol. Namun tetap dilandasi oleh sportivitas bertanding yang tinggi. Di samping Anda bersenang-senang, Megala-gala juga mengajari Anda untuk bersikap percaya diri, disiplin, kejujuran, semangat, kebersamaan, kerja sama, dan solidaritas. Oleh sebab itu magale-gala adalah suatu permainan yang bermanfaat baik dari segi pembinaan kesegaran jasmani anak maupun pendidikan mental anak[2].

c. Game Design

Dalam merancang sebuah Game, perancanggameharus melihatnya dalam berbagai sudut pandang.Menurut Schell[8], permainan yang menggunakan media elektronik, yang dibuat dengan teknik dan metode tertentu yang mempunyai potensi yang sangat besar dalam membangun motivasi mencapai tujuan. Terdapat beberapa kriteria yang harus diperhatikan untuk mengembangkan game dengan kualitas yang baik. Kriteria tersebut yaitu, functional game yang artinya fitur dan operasional yang dimiliki game tersebut. Selanjutnya yaitu internally complete, kriteria ini mencakup mengenai aturan, cabang, dan kondisi yang ada pada game. Balanced, menunjukkan kesulitan dari suatu permainan, gametidak terlalu sulit dan gametidak terlalu mudah. Fun merupakan dalam sebuah permainan harus bisa menarik, menghibur, menantang, dan membuat pemain ingin memainkannya kembali. Kriteria terakhir yaitu Accessible dalam permainan harus mudah digunakan dan dipahami oleh semua pengguna dan terdapat beberapa sudut pandang yang dapat digunakan untuk merancang sebuah Game yang baik.

Menurut Schell [8], terdapat 113 lenses theory, dari 113 lenses theory tersebut dianalisis dan dapat dikelompokkan menjadi beberapa kategori, berikut kategori dari masingmasing lenses theorydilihat pada Tabel 1.

Tabel1. Kategori Lenses Theory
Volume 8, Nomor 2, Tahun 2019

\begin{tabular}{|l|l|l|}
\hline No & \multicolumn{1}{|c|}{ Kategori } & \multicolumn{1}{c|}{$\begin{array}{c}\text { Nomor Lenses Theory Desain } \\
\text { Game }\end{array}$} \\
\hline 1 & Emosi Pengguna & $\begin{array}{l}1,5,6,12,17,20,35,69,70, \\
71,94,95,100,106\end{array}$ \\
\hline 2 & $\begin{array}{l}\text { Pengalaman } \\
\text { Pengguna }\end{array}$ & $\begin{array}{l}2,13,24,30,37,38,39,40, \\
56,65,68,72,77,79,83,110\end{array}$ \\
\hline 3 & Penghargaan & $4,25,46,47,63,80$ \\
\hline 4 & $\begin{array}{l}\text { Tujuan dan } \\
\text { peraturan game }\end{array}$ & $8,9,10,14,21,32,33,34$ \\
\hline 5 & Karakteristik game & $\begin{array}{l}18,27,28,29,48,49,52,53, \\
75,92,93,99\end{array}$ \\
\hline 6 & Perspektif Pengguna & $19,22,23,54,55,81$, \\
\hline 7 & $\begin{array}{l}\text { Keterampilan } \\
\text { Pemain }\end{array}$ & $31,36,41,42,57,58,74$ \\
\hline 8 & Komunitas Game & $43,44,45,96,97,98$ \\
\hline 9 & Karakter Game & $50,82,85,86,87,88,89,90$, \\
& & $\begin{array}{l}3,7,51,59,60,61,62,64,66, \\
67\end{array}$ \\
\hline 10 & $\begin{array}{l}\text { Tampilan } \\
\text { Permainan }\end{array}$ & $11,26,73,76,78,84$ \\
\hline 11 & $\begin{array}{l}\text { Jalan Cerita dan } \\
\text { Tema Permainan }\end{array}$ & $\begin{array}{l}15,16,101,102,103,104, \\
105,107,108,109,111,112, \\
113\end{array}$ \\
\hline 12 & $\begin{array}{l}\text { Pengujian dan } \\
\text { Pemasaran game }\end{array}$ & \\
\hline
\end{tabular}

\section{d. UML}

UML (Unified Modeling Languange) adalah sebuah notasi diagram yang tepat dan memungkinkan mewakili rancangan program yang dibahas yang bersifat grafis yang berdasarkan grafik atau gambar untuk memvisualisasi, memahami, mendiskusikan, menspesifikasikan, membangun, dan pendokumentasian informasi yang disajikan dalam diagram dari sebuah pengembangan perangkat lunak berbasis OOP (Object-Oriented Programing)[11]. Kennet E dan Julie E Kendall[12] mendeskripsikan gambaran keseluruhan diagram uml yang menunjukkan bagaimana setiap diagram mengarah pada pengembangan diagram uml lainnya, berikut gambaran dari pengembangan UML diagrampada Gambar 1.

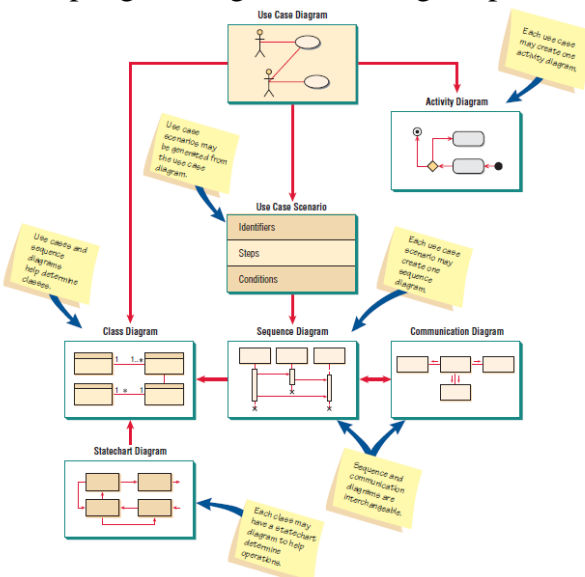

Gambar 1. Pengembangan UML Diagram [12] 
ISSN 2252-9063

Kumpulan Artikel Mahasiswa Pendidikan Teknik Informatika

(KARMAPATI)

Seperti yang terlihat pada gambar di atas dijelaskan bagian-bagian dari pengembangan UML diagram, yaitu use case diagram, activity diagram, use case scenario, sequence diagram, communication diagram, state chart diagram, dan class diagram. Masing-masing diagram mempunyai fungsi masing-masing untuk menggambarkan sebuah pengembangan aplikasi.

e. GDLC

Game Development Life Cycle (GDLC) adalah metode pengembangan suatu game. Dimana dalam metode ini terdiri enam tahap yang harus dilalui agar pengembangan suatu game dapat menjadi optimal, tahapan tersebut antara lain tahap initiation, pre-production, production, testing, beta dan tahap release[13].Tahapan metode GDLCdilihat pada Gambar 2 .
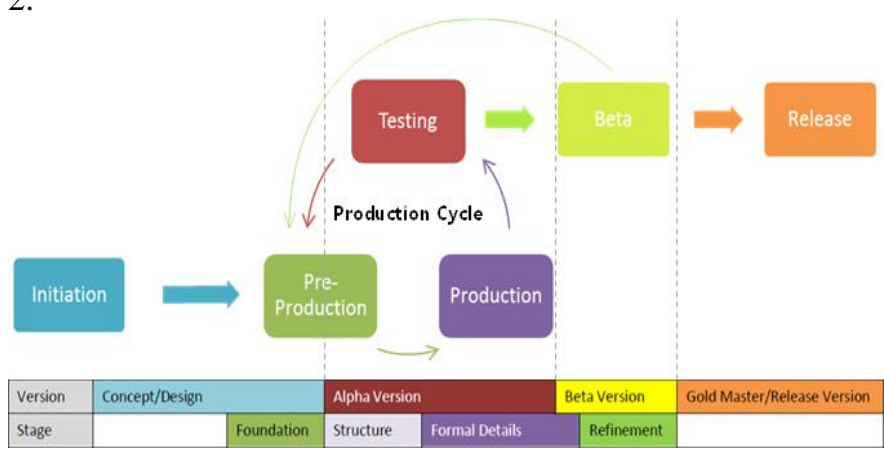

Gambar 2. Tahapan Game Development Life Cycle[13]

f. Unity

Unity merupakan suatu aplikasi yang digunakan untuk mengembangkan game multiplatform yang didesain untuk mudah digunakan. Unity itu bagus dan penuh perpaduan dengan aplikasi yang profesional. Grafis pada unity dibuat dengan grafis tingkat tinggi untuk OpenGL dan directX. Unity mendukung semua format file, terutamanya format umum seperti semua format dari art applications. Lingkungan dari pengembangan Unity berjalan pada Microsoft Windows dan Mac OS X, serta aplikasi yang dibuat oleh Unity dapat berjalan pada Windows, Mac, Xbox 360, Playstation 3, Wii, iPad, iPhone dan tidak ketinggalan pada platform Android. Unity juga dapat membuat game berbasis browser yang menggunakan Unity web player plugin, yang dapat bekerja pada Mac dan Windows, tapi tidak pada Linux. Web player yang dihasilkan juga digunakan untuk pengembangan pada widgets Mac[14].

\section{METODOLOGI PENELITIAN}

Pengembangan game tradisional "Megala-gala" berbasis android ini menggunakan metode GDLC (Game Development Life Cycle). Prosedur pengembangan dalam model GDLC terdiri dari enam tahap, keenam tahap tersebut adalah Initiation, Pre-Production, Production, Testing, Beta dan Release. Skema metode GDLC dari penelitian inidilihat pada Gambar 3.

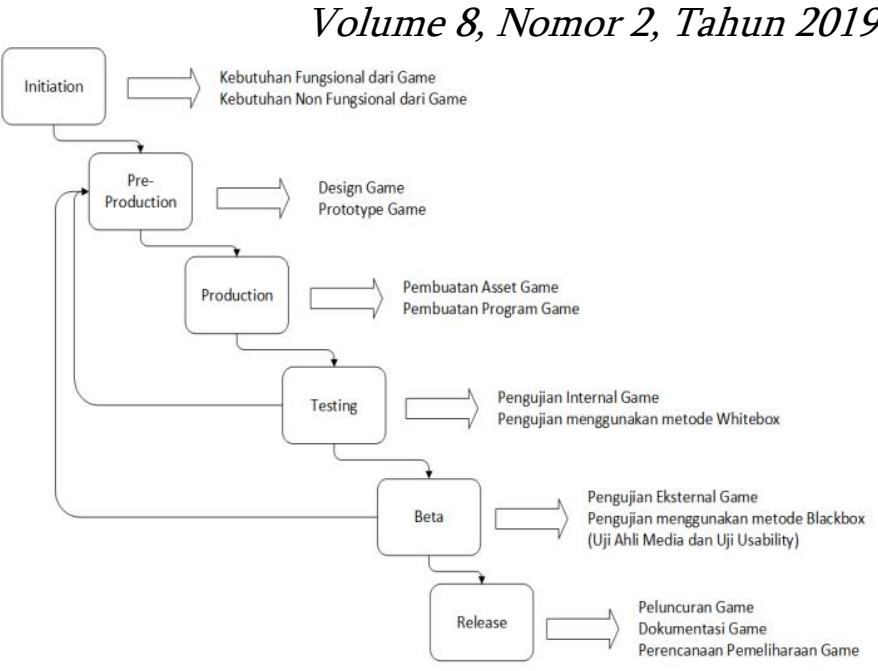

Gambar 3. Skemametode GDLC

Dari gambar 3di atas terlihat bahwa setiap tahapan dalam metode GDLC saling berkaitan. Adapun peneliti lakukan dalam laporan penelitian ini adalah :

A. Initiation

Tahap Initiation merupakan tahap pertama yang dilakukan dalam menciptakan sebuah game, dengan menciptakan konsep kasar seperti apa game yang akan dibuat serta gagasan dan konsep dari game tersebut. Pada tahap ini dilakukan pencarian referensi mengenai teori-teori terkait yang diperlukan dan bagaimana menerapkannya dalam pengembangan sebuah aplikasi yaitu game.

Pada tahap ini akan dipaparkan mengenai tahapan awal dari perangkat lunak yang akan dikembangkan, yaitu: kebutuhan perangkat lunak, tujuan perangkat lunak, masukan dan keluaran perangkat lunak.

\section{B. Pre-Production}

Tahap Pre-production adalah salah satu tahap pertama dan terpenting dari production cycle. Pada tahap preproduction ini melibatkan penciptaan dan revisi design game dan pembuatan prototype game.

Pada tahap ini dirancang Game Design dan Prototype meliputi Game Description, Game Leveling, Game Rules, Victory Condition, Lost Condition.

\section{Production}

Tahap Prodution adalah tahap inti yang berkisar pada penciptaan asset, pembuatan source code dan integrasi kedua elemen tersebut. Dalam tahap pre-production, sebelumnya telah disusun kerangka game. Dalam tahap production ini, kerangka yang masih konseptual tersebut direalisasikan menjadi produk yang siap ditesting.

D. Testing

Tahap Testing adalah tahap dimana aplikasi telah siap untuk diperkenalkan dan dilakukan pengujian kelayakan. Pengujian dalam konteks ini berarti pengujian internal untuk menguji usability dan playability. Pengujian ini dilakukan dengan tujuan untuk memastikan game yang telah dibangun berdasarkan rancangan yang dibuat, sudah benar dan setiap 
fungsi yang terdapat pada game dapat berjalan dengan baik. Pada tahap testing, pengembang sistem harus bisa meminimalisir kesalahan (error) yang terjadi pada sistem dan memastikan keluaran sistem sesuai dengan apa yang diinginkan

E. Beta

Tahap Beta adalah tahap dimana aplikasi dilakukan pengujian pihak ketiga atau eksternal. Prototipe terkait dalam pengujian beta adalah rincian formal dan penyempurnaan.

Kriteria kualitas dalam beta terkait erat dengan tahap prototipe. Dalam pengujian rincian formal, penguji diminta untuk menemukan bug (terkait dengan kriteria kualitas fungsional dan internal yang lengkap). Dalam pengujian penyempurnaan, penguji diberi kebebasan lebih untuk menikmati permainan, karena tujuannya lebih diarahkan untuk mendapatkan umpan balik (terkait dengan kriteria kualitas menyenangkan dan aksesibilitas).

\section{F. Release}

Pada tahap release ini berarti produk game atau aplikasi yang dikembangkan sudah siap untuk dilepas atau diperkenalkan ke publik secara umum. Pelepasan produk melibatkan peluncuran produk, dokumentasi produk dan perencanaan untuk pemeliharaan dan perluasan permainan.

\section{HASIL \&PEMBAHASAN}

HASIL

Hasil evaluasi model penelitian merupakan proses menjalankan dan mengevaluasi sebuah perangkat lunak berdasarkan model penelitian yang digunakan untuk menguji apakah perangkat lunak sudah memenuhi persyaratan atau belum untuk menentukan perbedaan antara hasil yang diharapkan dengan hasil sebenarnya.

Berikut ini akan dijabarkan mengenai beberapa tahapan terkait dengan hasil evaluasi dari Game Tradisional Megala-gala berbasis android yaitu tahap Initation, tahap PreProduction, tahap Production, tahap Testing, tahap Beta dan tahap Release.

\section{A. Initiation}

Pada tahap ini akan dipaparkan mengenai tahapan awal dalam pengembangan game yaitu dimulai dengan mencari tahu tentang permainan tradisional dan perlunya permainan tradisional ini dikembangkan menjadi game yang berbasis android. Peneliti melakukan survei dengan menyebarkan angket kuisioner tentang permainan tradisional megala-gala. Peneliti juga melakukan wawancara kepada bapak Made Taro selaku tokoh pelestari permainan tradisional bali. Dari hasil wawancara tersebut bapak Made Taro sangat antusias dan mendukung permainan tradisional bali salah satunya yaitu megala-gala diadobsi kedalam game berbasis android guna untuk mengenalkan dan melestarikan permainan tradisional megala-gala.

Setelah mendapatkan data dan teori tentang permainan tradisional megala-gala merujuk pada lenses theory[8] peneliti akan menerapkan beberapa lenses theory dalam perancangan dan pengembangan game tradisional megala-gala. Lenses theory yang akan diterapkan dilihat pada Tabel 2.

Tabel2. Lenses Theory yang akanditerapkan

\begin{tabular}{|l|l|l|}
\hline No & \multicolumn{1}{|c|}{ Kategori } & \multicolumn{1}{|c|}{$\begin{array}{c}\text { Nomer Lenses } \\
\text { Theory Desain Game }\end{array}$} \\
\hline 1 & Emosi Pengguna & 1,5 \\
\hline 2 & Pengalaman Pengguna & 38,56 \\
\hline 3 & Penghargaan & $4,46,47,63,80$ \\
\hline 4 & Tujuan dan peraturan game & 33 \\
\hline 5 & Karakteristik game & 53 \\
\hline 6 & Perspektif Pengguna & 54 \\
\hline 7 & Keterampilan Pemain & 31,74 \\
\hline 8 & Komunitas Game & 43 \\
\hline 9 & Karakter Game & 82 \\
\hline 10 & Tampilan Permainan & $3,7,59,62,64$ \\
\hline 11 & $\begin{array}{l}\text { Jalan Cerita dan Tema } \\
\text { Permainan }\end{array}$ & 11 \\
\hline 12 & $\begin{array}{l}\text { Pengujian dan Pemasaran } \\
\text { game }\end{array}$ & $102,103,108,113$ \\
\hline
\end{tabular}

Dari penerapan lenses theory pada tahap initiation didapatkan kebutuhan perangkat lunak, tujuan perangkat lunak, masukan dan keluaran perangkat lunak.

B. Pre-Production

Pada tahap ini dirancang Game Design dan Prototype meliputi Game Description, Game Leveling, Game Rules, Victory Condition, Lost Condition.

a. Model Fungsional Perangkat Lunak.

1. Use Case Diagram

Untuk mengenal proses utama suatu sistem digunakan use case diagram. Dengan use case diagram ini dapat diketahui proses yang terjadi pada aplikasi beserta pelakunya. Menurut Gould [15] menyatakan use case digunakan untuk menunjukkan fungsionalitas sebuah sistem dari perspektif pengguna dan menggambarkan bagaimana pengguna berinteraksi dengan sistem dalam situasi tertentu. Use case diagram dari permainan tradisional megala-gala dilihat pada Gambar 4.

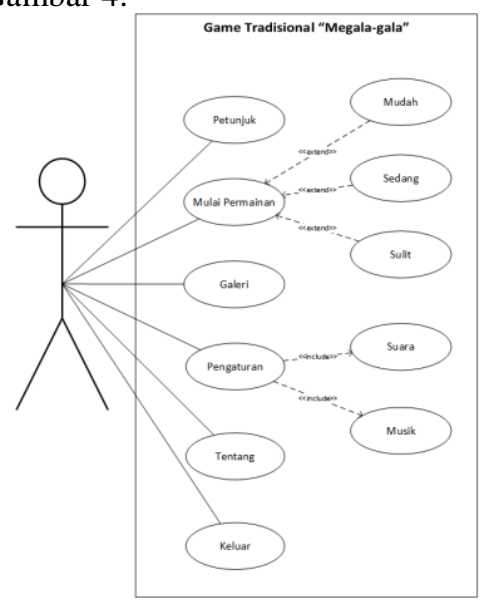


ISSN 2252-9063

Kumpulan Artikel Mahasiswa Pendidikan Teknik Informatika

(KARMAPATI)

KarmapaT

Gambar 4. Use Diagram Game TradisionalMegala-gala

2. Activity Diagram

Activity Diagram adalah salah satu cara untuk memodelkan event-event yang terjadi dalam suatu use case. Menurut Gould [15] menyatakan activity diagram digunakan untuk menunjukkan tindakan atau kejadian dalam suatu urutannya, bersamaan dengan hasilnya.Activity diagram dari penelitian ini dilihat pada Gambar 5.

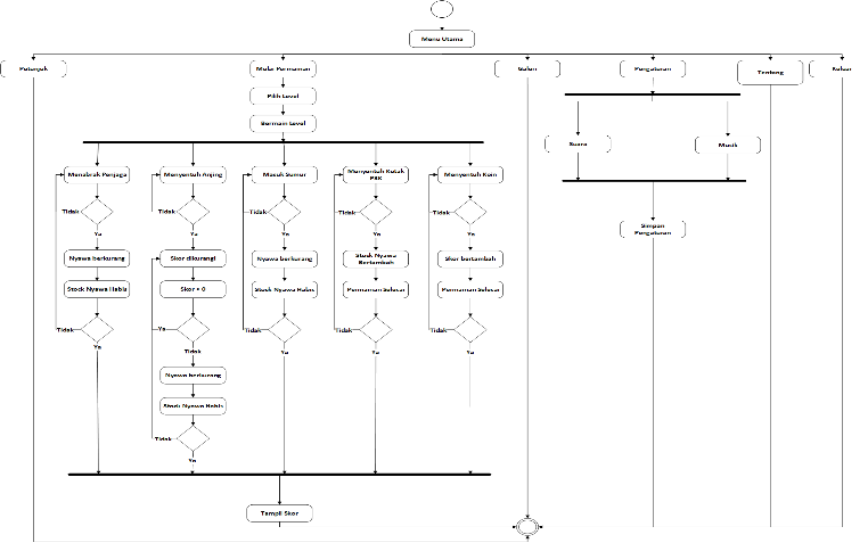

Gambar 5. Activity Diagram Game TradisionalMegala-gala

b. Perancangan Perangkat Lunak

1. Batasan Perancangan Perangkat Lunak

Dengan melihat permasalahan yang terjadi maka dapat dibuat suatu game sesuai batasan masalah sebagai berikut.

1). Game yang dikembangkan diperuntukan untuk bisa diakses secara offline.

2). Game Tradisional "Megala-gala" berbasis android ini dirancang dengan visual 2 dimensi.

3). Game Tradisional "Megala-gala" berbasis android ini mampu berjalan pada platform android minimum versi 2.3 (Gingerbread).

4). Game Tradisional "Megala-gala" berbasis android ini dirancang untuk dimainkan Single Player.

5). Implementasi Game Tradisional "Megala-gala" berbasis android ini hanya bisa dijalankan di platform Android.

6). Implementasi Game "Megala-gala" berbasis android ini lebih ditekankan penggunaannya pada anak-anak, namun tidak menutup kemungkinan dimainkan juga oleh orang dewasa dengan minimal usia 8 tahun.

7). Implementasi Game Tradisional "Megala-gala" berbasis android ini dikembangkan mempunyai 3 tingkatan level, yaitu level mudah, sedang dan sulit yang mempunyai tingkatan dan kesulitan masing-masing

2. Perancangan Struktur Navigasi

Struktur Navigasi merupakan struktur atau alur dari suatu program. Struktur Navigasi juga memberikan kemudahan dalam menganalisa keinteraktifan seluruh objek dalam aplikasi dan bagaimana pengaruh keinteraktifannya terhadap pengguna. Rancangan struktur navigasi game megalagaladilihat pada Gambar 6.

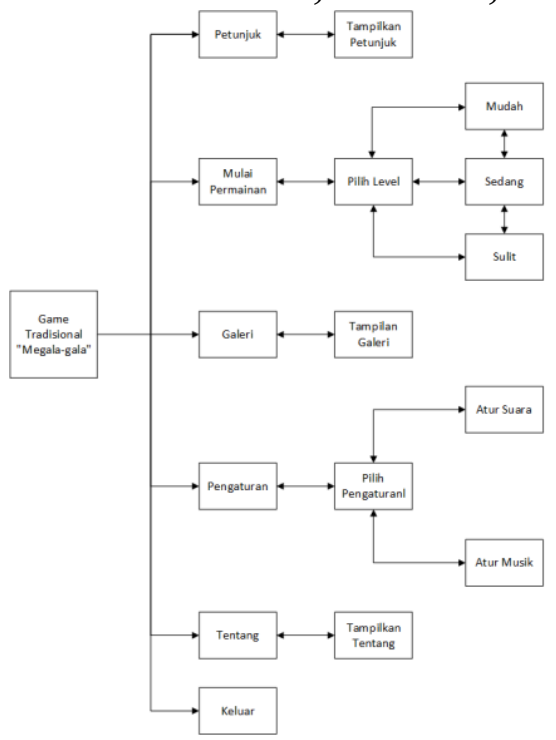

Gambar 6. PerancanganStrukturNavigasi

3. Desain Karakter

Dalam pengembangan aplikasi game yang akan dibuat ada beberapa karakter yang ada dalam game, yaitu karakter sebagai team serang, team jaga, dan karakter pendukung seperti karakter anjing, karakter sumur, karakter koin dan karakter kotak p3k. Karakter yang digunakan ditunjukan pada gambar berikut :

1). Karakter Team Serang

Karakter team serang dilihat pada Gambar 7.
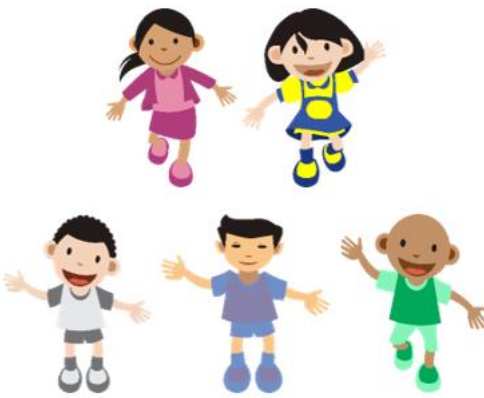

Gambar 7. Karakter Team Serang

2). Karakter Team Jaga

Karakter team jaga dilihat pada Gambar 8.

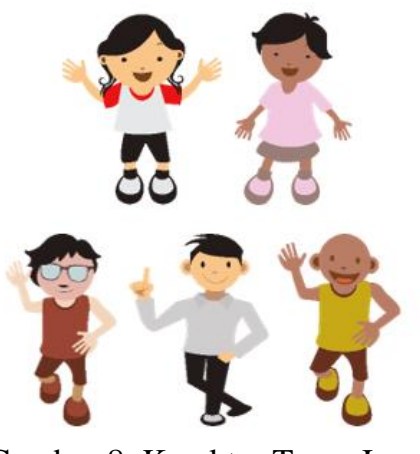

Gambar 8. Karakter Team Jaga 
3). Karakter Pendukung

Karakter pendukung dilihat pada Gambar 9.

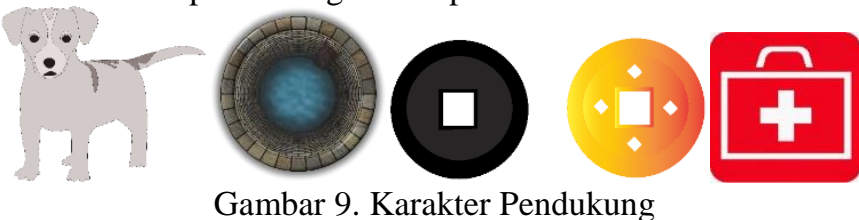

4. Perancangan Antarmuka Perangkat Lunak

Perancangan antarmuka perangkat lunak merupakan proses membangun antarmuka aplikasi yang akan digunakan untuk berinteraksi antara pengguna dengan perangkat lunak. Rancangan yang dibuat bersifat pengguna friendly dimana bertujuan agar pengguna merasa tertarik, nyaman, dan mudah dalam memainkannya.

Perancangan antarmuka perangkat lunak Game Tradisional Megala-gala berbasis Android adalah sebagai berikut.

1). Rancangan Antarmuka Splashscreen

Tampilan Splashscreen ini muncul saat pertama kali game atau sistem berjalan. Berisi logo identitas kampu. Rancangan antarmuka splashscreendilihat pada Gambar 10 .

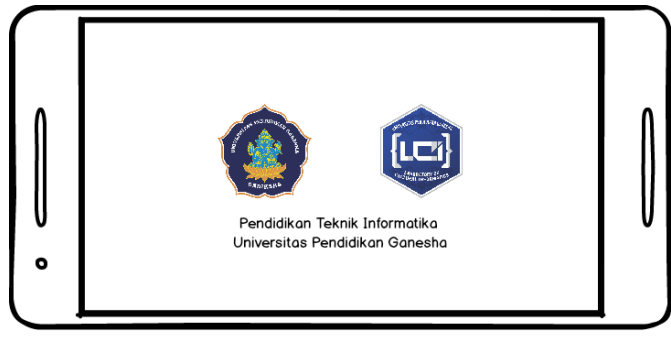

Gambar 10. RancanganAntarmukaSplashscreen

2). Rancangan Antarmuka Menu Utama

Tampilan Menu utama berisi menu-menu yang ada dalam game yaitu, menu petunjuk, main, galeri, pengaturan, tentang, keluar. Terdapat pula gambar latar dari game. Rancangan antarmuka splashscreendilihat pada Gambar 11.

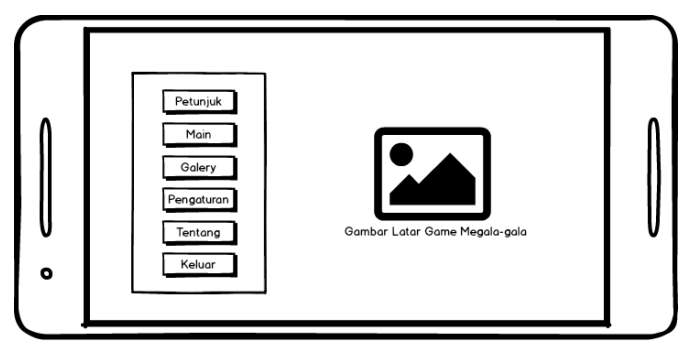

Gambar 11. RancanganAntarmuka Menu Utama

3). Rancangan Antarmuka Main Level Mudah

Pada main level mudah, terdapat 3 pemain dan 3 penjaga. Selain itu terdapat koin untuk menambah skor dan anjing sebagai pengganggu permainan. Untuk bermain sudah disiapkan navigasi arah dan tombol pilihan pemain dan juga terdapat tombol untuk kembali ke menu utama. Terdapat tampilan nyawa dan point yang diperoleh dalam bermain. Rancangan antarmuka main level mudah dilihat pada Gambar 12.

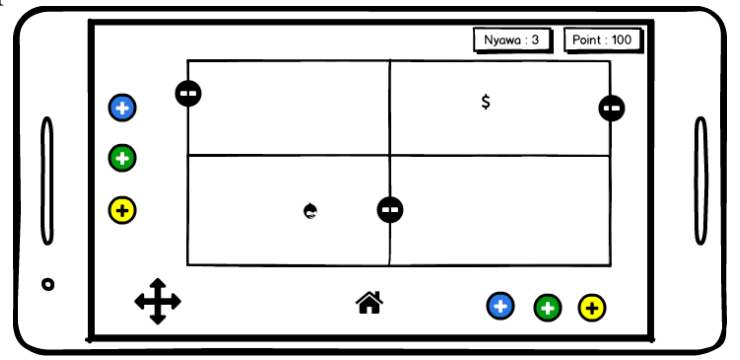

Gambar 12. RancanganAntarmuka Main Level Mudah

4). Rancangan Antarmuka Main Level Sedang

Pada main level sedang, terdapat 4 pemain dan 4 penjaga, terdapat tambahan kotak p3k untuk menambah nyawa pemain bila disentuh oleh pemain. Rancangan antarmuka main level sedang dilihat pada Gambar 13

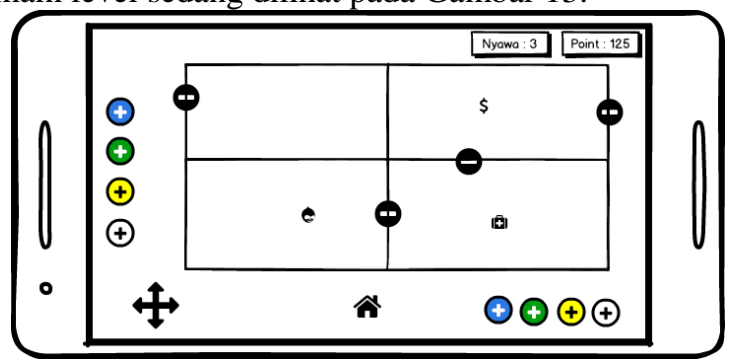

Gambar 13. RancanganAntarmuka Main Level Sedang

5). Rancangan Antarmuka Main Level Sulit

Pada main level sulit, terdapat 5 pemain dan 5 penjaga, terdapat tambahan rintangan sumur yang muncul secara acak, bila pemain masuk ke sumur maka permain akan mati atau nyawa pemain berkurang. Rancangan antarmuka main level sulit dilihat pada Gambar 14.

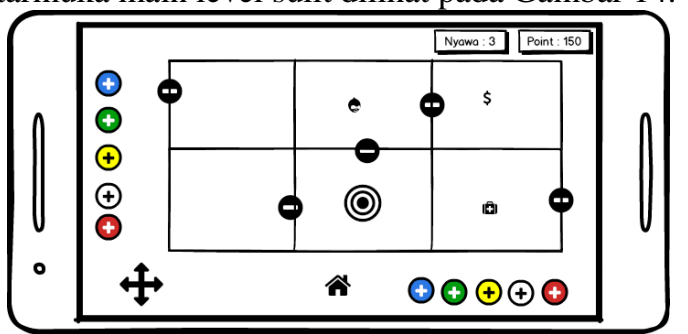

Gambar 14. RancanganAntarmuka Main Level Sulit

C. Production

Tahap inti yang berkisar pada penciptaan asset, pembuatan source code dan integrasi kedua elemen tersebut. Dalam tahap pre-production, sebelumnya telah disusun kerangka game. Dalam tahap production ini, kerangka yang masih konseptual tersebut direalisasikan menjadi produk yang siap ditesting.

a. Hasil Layar Antarmuka

Hasil layar antarmuka dilakukan berdasarkan rancangan antarmuka yang telah dilakukan. Kesesuaian Rancangan dan Implementasi Antarmuka sebagai berikut. 
ISSN 2252-9063

Kumpulan Artikel Mahasiswa Pendidikan Teknik Informatika

(KARMAPATI)

KARMAPATI

1). Layar Antarmuka Splashscreen

Hasil antarmuka splashscreen dilihat pada Gambar 15.

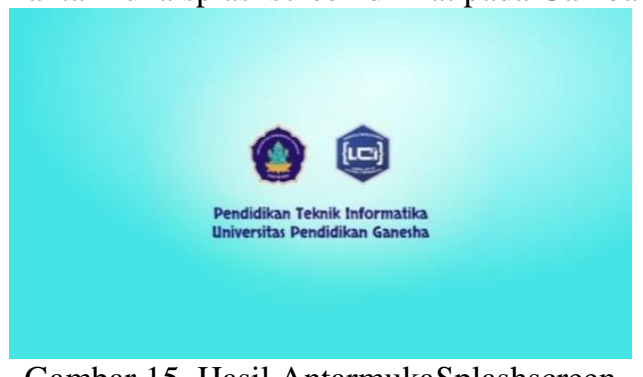

Gambar 15. Hasil AntarmukaSplashscreen

2). Layar Antarmuka Menu Utama

Hasil antarmuka menu utama dilihat pada Gambar 16.

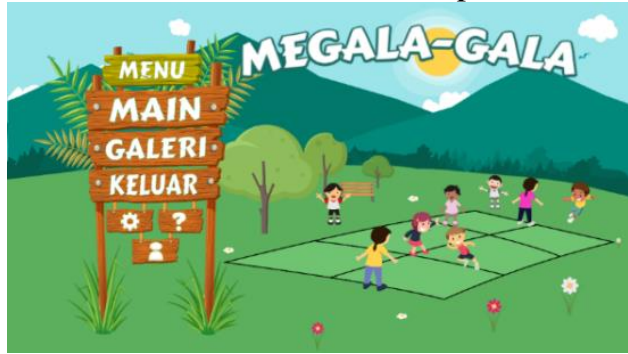

Gambar 16. Hasil Antarmuka Menu Utama

3). Layar Antarmuka Main Level Mudah

Hasil antarmuka main level mudah dilihat pada Gambar 17.

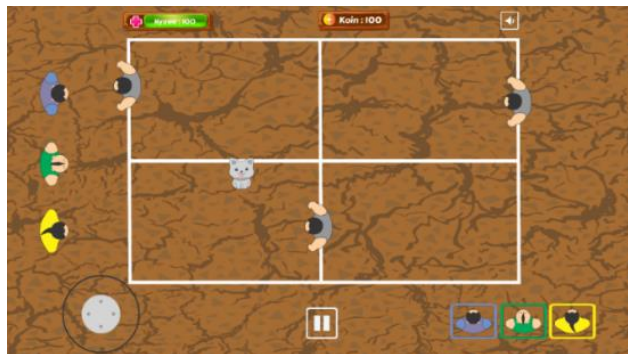

Gambar 17. Hasil Antarmuka Main Level Mudah

4). Layar Antarmuka Main Level Sedang

Hasil antarmuka main level sedang dilihat pada Gambar 18.

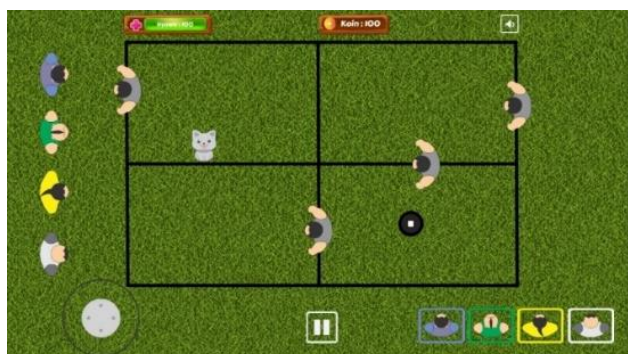

Gambar 18. Hasil Antarmuka Main Level Sedang

5). Layar Antarmuka Main Level Sulit

Hasil antarmuka main level sulit dilihat pada Gambar 19.
Volume 8, Nomor 2, Tahun 2019

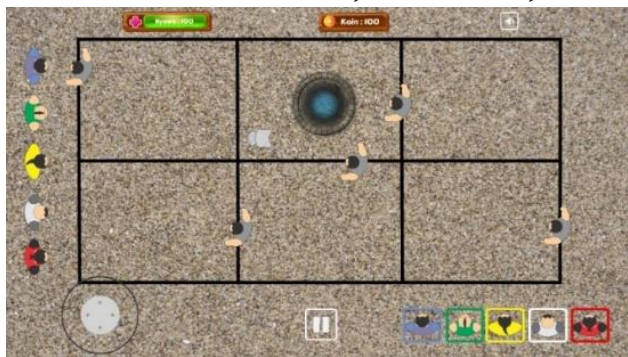

Gambar 19. Hasil Antarmuka Main Level Sulit

D. Testing

Tahap Testing adalah tahap dimana aplikasi telah siap untuk diperkenalkan dan dilakukan pengujian kelayakan. Pengujian dalam konteks ini berarti pengujian internal untuk menguji usability dan playability. Pengujian yang dilakukan dengan Uji Whitebox.

a. Whitebox

Pengujian Whitebox merupakan metode desain test case yang menggunakan struktur kontrol dari desain prosedural untuk memperoleh test case. Uji Whitebox menggunakan struktur data internal untuk menjamin validitasnya [16]. Pada pengujian Whitebox ini dilakukan oleh pengembang sendiri dan bebrapa orang dibidangnya.

E. Beta

Tahap Beta adalah tahap dimana aplikasi dilakukan pengujian pihak ketiga atau eksternal. Pengujian beta menggunakan pengujian blackbox, karena prototipe terkait dalam pengujian beta adalah rincian formal dan penyempurnaan. Pengujian yang dilakukan dengan Uji blackbox.

a. Blackbox

Pengujian Blackbox, juga disebut uji perilaku, berfokus pada persyaratan fungsional dari perangkat lunak. Menurut Roger S. Pressman [16] Black Box Testing atau Pengujian Kotak Hitam atau juga disebut Behavioral Testing, berfokus pada persyaratan fungsional dari perangkat lunak. Artinya, teknik Black Box Testing memungkinkan untuk mendapatkan set kondisi masukan yang sepenuhnya akan melaksanakan semua persyaratan fungsional untuk suatu program. Uji Blackbox ditujukan ke responden diluar pengembang. Pada pengujian ini memerlukan responden untuk Uji Ahli Media, Uji Ahli Isi dan Uji Usabilty.

1. Uji Ahli Media

Uji ahli media memvalidasi terhadap ketepatan tata letak bentuk atau interface, visual design dari aplikasi yang dirancang [17]. Uji media dilakukan dengan menggunakan angket yang melibatkan ahli dalam bidang media game berbasis Android

Pengujian ahli media pada game megala-gala ini melibatkan dua orang ahli yang merupakan dosen di jurusan pendidikan teknik informatika universitas pendidikan ganesha, fokus penilaian dalam pengujian ini ada dua, yaitu pertama tampilan aplikasi dengan indikator penilaian pewarnaan, grafis, interaktif menu dan ikon. Fokus penilaian kedua yaitu 
ISSN 2252-9063

Kumpulan Artikel Mahasiswa Pendidikan Teknik Informatika

(KARMAPATI)

kualitas teknis dengan indikator pengoperasian aplikasi, keamanan aplikasi, penanganan kesalahan

2. Uji Ahli Isi

Pengujian ahli isi digunakan untuk mengetahui isi dari materi yang ingin disampaikan melalui aplikasi. Pengujian dilakukan untuk menjamin bahwa isi materi sesuai dengan permainan tradisional megala-gala. Pengujian dilakukan untuk memvalidasi indikator experience, goal of education, dan learning [18]. Uji isi dilakukan dengan menggunakan angket yang melibatkan ahli dalam bidang permainan tradisional

Pada pengujian ahli melibatkan seorang ahli dalam bidang permainan tradisional yaitu bapak Made Taro selaku tokoh pelestari permainan tradisional bali. Dari hasil pengujian ahli isi, bapak Made Taro memberikan komentar bahwa beliau sangat mendukung dan mengapresiasi permainan tradisional bali salah satunya megala-gala dijadikan game berbasis android, ini merupakan salah satu cara untuk memperkenalkan dan melestarikan permainan tradisional bali yang kian dilupakan.

3. Uji Usability

Uji Usabilitas adalah uji untuk user-friendliness [16]. Pengujian dilakukan untuk memvalidasi indikator main menu state dan game state dengan melakukan uji penggunaan aplikasi di perangkat berbeda, kebenaran proses aplikasi masing-masing menu dan kelayakan dari aplikasi [19]. Uji Usabilitas dilakukan melalui kuisioner yang melibatkan masyarakat umum sebanyak 50 orang sebagai pengguna aplikasi dengan rincian 40 orang pelajar (Tingkat SD 20 orang, SMP 10 orang dan SMA 10 orang) dan 10 orang dewasa.

Pada pengujian usability dibagi dalam beberapa kasus penilaian yaitu pertama, uji kasus 1 : penggunaan aplikasi pada perangkat android yang berbeda, dalam pengujian ini melibatkan 14 orang dengan 14 merk tipe perangkat android yang berbeda. Berikut gambaran grafik hasil uji kasus 1 : penggunaan aplikasi pada perangkat android yang berbeda. Hasil uji kasus 1 : penggunaan aplikasi pada perangkat android yang berbedadilihat pada Gambar 20.

Uji Kasus 1 : Pengunaan aplikasi pada perangkat yang berbeda

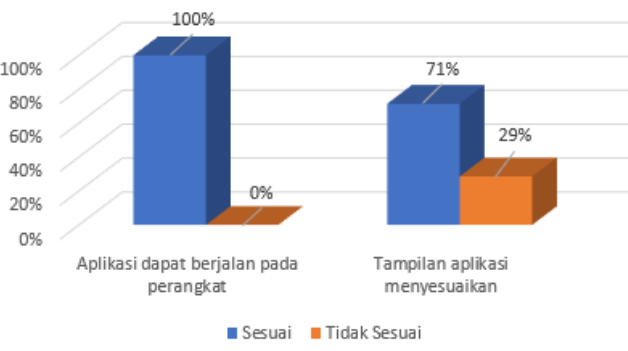

Gambar 20. Grafik Hasil Uji Kasus 1

Hasil pengujian menyatakan bahwa game dapat berjalan pada semua perangkat android yang digunakan
Volume 8, Nomor 2, Tahun 2019

namun pada pengujian penyesuaian tampilan pada perangkat didapatkan $29 \%$ tipe perangkat, tampilan tidak menyesuaikan dengan baik.

Kedua, uji kasus 2 : kebenaran proses aplikasi, dalam pengujian ini melibatkan 14 orang dengan 14 merk tipe perangkat android yang berbeda. Pengujian ini untuk mengetahui bahwa proses yang ada dalam game sudah berjalan dengan benar dan sesuai dengan fungsinya. Hasil pengujian menyatakan bahwa semua proses sudah berjalan dengan benar dan sesuai dengan fungsinnya pada perangkat yang digunakan dalam pengujian. Hasil uji kasus 2 : kebenaran proses aplikasidilihat pada Gambar 21.

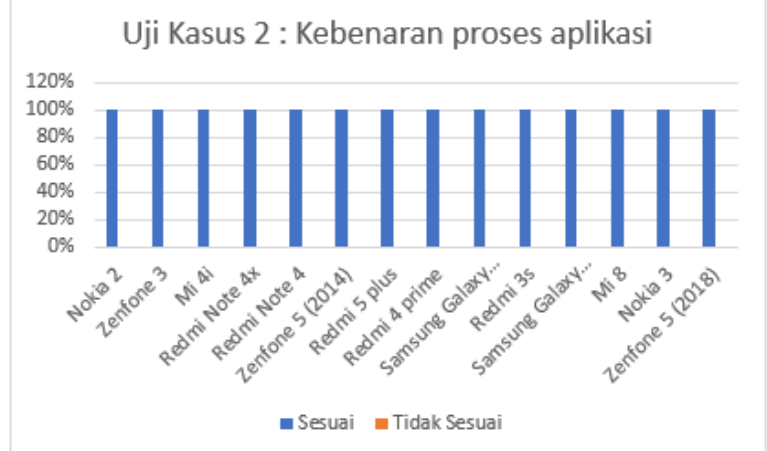

Gambar 21. Grafik Hasil Uji Kasus 2

Ketiga, uji kasus 3 : tampilan, kualitas teknis dan leveling, pengujian ini melibatkan 50 orang responden mulai dari anak sekolah dasar sampai dengan orang dewasa. Hasil uji kasus 3 : tampilan, kualitas teknis dan levelingdilihat pada Gambar 22.

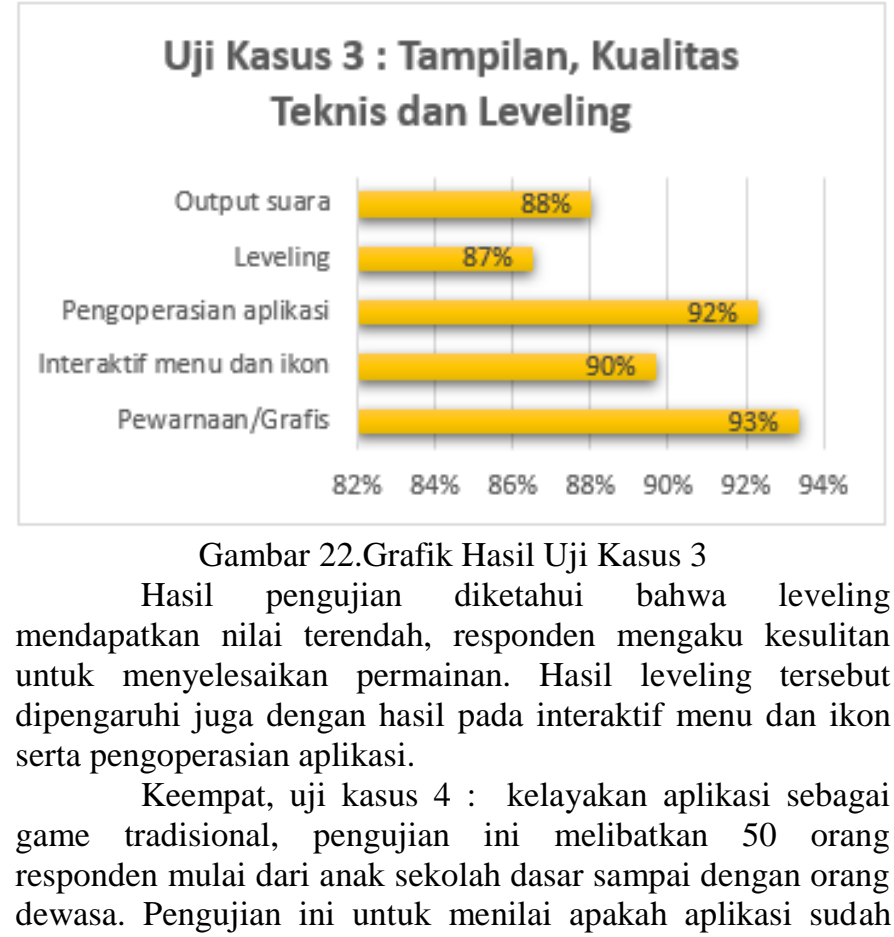


layak menjadi sarana pengenalan permainan tradisional megala-gala. Hasil uji kasus 4 : kelayakan aplikasi sebagai game tradisionaldilihat pada Gambar 23.

\section{Uji Kasus 4 : Kelayakan Aplikasi Sebagai Game Tradisional}
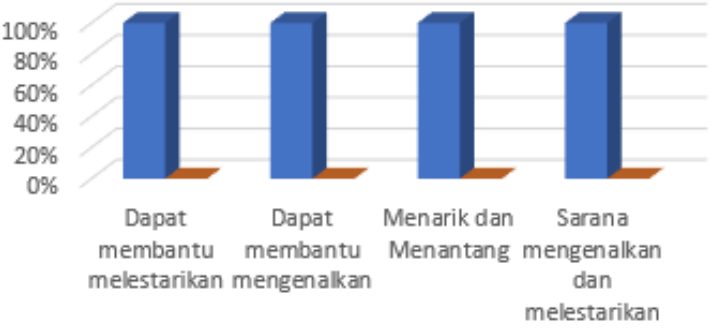

- Sesuai n Tidak Sesuai

Gambar 23. Grafik Hasil Uji Kasus 4

Hasil pengujian menyatakan bahwa aplikasi sudah layak untuk dijadikan sebagai salah satu sarana atau media dalam mengenalkan dan melestarikan permainan tradisional, khususnya permainan tradisional megala-gala

F. Release

Tahap release merupakan tahap akhir dari metode GDLC, produk game yang dibuat sudah dalam bentuk .apk dan sudah siap untuk disebarluaskan ke kalangan umum. Pada tahap ini dilakukan peluncuran game dan dokumentasi game yang berisi cara pemasangan dan penggunaan dari game tradisional megala-gala berbasis android.

Produk game atau aplikasi yang diluncurkan untuk kalangan umum tersebut diharapkan nantinya akan mendapatkan kritikan atau masukan dari berbagai pengguna, kritikan atau masukan tersebut nantinya akan berguna untuk dilakukan pemeliharaan atau perbaikan dari game tersebut. Game tradisional megala-gala berbasis android ini diharapkan dapat menjadi sarana alternatif pengenalan permainan tradisional serta nilai-nilai yang terkandung dalam permainan tradisional megala-gala.

\section{PEMBAHASAN}

Pengembangan game tradisional megala-gala dikembangkan dengan metode GDLC (Game Development Life Cycle) dengan 6 tahapan yaitu tahap initiation, tahap pre-production, tahap production, tahap testing, tahap beta dan tahap release. Tahap pertama adalah initiation, pada tahap ini akan dipaparkan mengenai tahapan awal dalam pengembangan game. Setelah mendapatkan data dan teori tentang permainan tradisional megala-gala merujuk pada lenses theory [8] peneliti akan menerapkan beberapa lenses theory dalam perancangan dan pengembangan game tradisional megalagala.Lenses theory yang diterapkan diantaranya, Kategori Emosi Pengguna yaitu Lenses theory 1 yaitu memperhatikan emosi pemain, tema game ini adalah permainan tradisional yang difokuskan untuk anak-anak jadi peneliti membuat kondisi agar saat bermain emosi anak-anak bahagia dengan tampilan dan suara yang sesuai dengan anak-anak.Lenses theory 5 yaitu membuat pemain senang, peneliti membuat suatu kondisi dimana saat pemain dapat menyelesaikan permainan akan mendapatkan berupa reward dan skor tertinggi itu membuat pemain merasa senang dalam memainkan game. Kategori Pengalaman Pengguna yaitu Lenses theory 38 yaitu tantangan dan lenses theory 56 yaitu tingkatan level, peneliti membuat game menjadi 3 level dan setiap level memiliki tantangan yang berbeda, pemain akan memulai dengan level mudah selanjutnya untuk memainkan level yang lebih tinggi pemain harus menyelesaikan level mudah terlebih dahuluuntuk membuat pemain mengerti bagaimana cara bermain dan aturan setiap level, dan UI lainnya dimana untuk mempermudah pemain dalam penggunaan aplikasi game. Kategori Penghargaan yaitu Lenses theory 4 yaitu kejutan dan lenses theory 46 yaitu hadiah, peneliti membuat suatu kondisi kejutan jika pemain dapat menyelesaikan level tertentu beberapa kali makan akan muncul tampilan hadiah dari level tersebut. Lenses theory 47 yaitu hukuman, dalam game terdapatpenjaga dan hambatan berupa anjing dan sumur, jika pemain melakukan kontak dengan penjaga dan hambatan makan akan mendapat hukumanberupa pengurangan nyama dan koin.Lenses theory 63 yaitu umpan balik dan lenses theory 80 yaitu pertolongan, peneliti membuat suatu tampilan navigasi guna untuk memudahkan pemain mengetahui aturan dan cara bermain game serta petunjuk dalam game guna mengoperasikan game sesuai dengan fungsinya. Kategori Tujuan dan Peraturan Game yaitu Lenses theory 33 yaitu aturan, setiap level pada game mempunyai aturan masing-masing yaitu aturan kondisi dimana pemain bisa menang dan bagaimana pemain bisa kalah. Implementasi lenses theory pada sub bab preproduction yaitu victory condition dan lost condition. Kategori Karakteristik Game yaitu Lenses theory 53 yaitu seimbang, game yang dibuat harus memiliki level yang tidak terlalu jauh antara pemain dan tantangan, dimana keseimbangan tersebut sudah diterapkan pada semua level yaitu dengan memainkan pada level mudah 3 vs 3 , level sedang 4 vs 4 dan level sulit 5 vs 5. Kategori Perspektif Pengguna yaitu Lenses theory 54 yaitu kemudahan akses, dimana peneliti membuat UI petunjuk untuk mengetahui menu dan apa fungsinya, UI navigasi. Kategori Keterampilan Pemain yaitu Lenses theory 31 yaitu aksi, peneliti membuat aturan dan batasan aksi yang boleh dilakukan oleh pemain, penjaga dan tantangan, disini pemain dapat bergerak bebas selama bermain namun dibatasi oleh garis pembatas jadi pemain tidak boleh keluar batas tersebut. Penjaga dapat bergerak menyesuaikan dengan garis lintasan yang menjadi tanggung jawabnya.Lenses theory 74 yaitu hambatan, peneliti membuat hambatan yang membuat setiap game mempunyai kesulitan berbeda. Misal pada level mudah, hambatan utama adalah penjaga garis perlintasan, kemudian hambatan tambahan berupa anjing yang dapatbergerak bebas 
sesuai dengan jangkauan batasan yang sudah ditentukan. Kategori Komunitas Game yaitu Lenses theory 43 yaitu kompetisi, menentukan siapa yang memiliki kemampuan paling hebat adalah suatu hal yang wajar dalam game. Peneliti membuat kondisi dimana jika pemain dapat menyelesaikan suatu level, pemain akan mendapatkan skor, jika skor yang didapatkan lebih besar dari skor tertinggi sebelumnya maka pemain akan mendapatkan pemberitahuan bahwa pemain telah berhasil menjadi pemain dengan nilai skor tertinggi saat ini. Kategori Karakter Game yaitu Lenses theory 82 yaitu kolusi atau sekongkolan, peneliti membuat aturan setiap level berbeda, contohnya pada level mudah yang bermain adalah 3 vs 3, untuk bisa memenangkan level tersebut pemain harus mengontrol 3 player untuk dapat bekerjasama atau bersengkongkol sehingga dapat melewati penjaga ata rintangan dan berhasil memenangkan permainan. Kategori Tampilan Permainan yaitu Lenses theory 3 yaitu lingkungan, game lebih difokuskan untuk diterapkan kepada anak-anak, jadi peneliti sebisa mungkin membuat tampilan agar sesuai dengan karakter anak-anak.Lenses theory 7 yaitu elemen pada game terlihat penting, elemen tersebut contohnya barnyawa pemain, skor pemain, dimana peneliti membuat tampilan bar nyawa dan skor agar terlihat dengan jelas sehingga pemain dalam bermain memperhatikan kondisi tersebut.Lenses theory 59 yaitu kontrol, peneliti membuat kontrol pemain untuk bergerak pada posisi kiri dan kontrol seleksi pemain pada posisi kanan.Lenses theory 62 yaitu interface yang sederhana dan lenses theory 64 yaitu interface yang menarik, peneliti membuat tampilan sederhana dalam game yaitu penempatan menu, tombol dan informasi yang dapat dengan mudah ditemukan dan dimengerti sehingga pada saat pemain baru memainkan game akan langsung tahu dan mengerti bagaimana game tersebut. Walaupun dengan tampilan sederhana peneliti membuat perpaduan warna yang cocok sehingga tampilan menjadi lebih menarik. Kategori Jalan Cerita dan Tema Permainan yaitu Lenses theory 11 yaitu penyatuan, element game ini adalah suatu permainan tradisional, diterapkan untuk anak-anak, peneliti menyatukan element tersebut sehingga dapat menciptakan game yang sesuai dengan anak-anak dan permainan tradisional dengan membuat tampilan bertema anak-anak dan mempertahankan peraturan penting dalam permainan tradisional megala-gala. Kategori Pengujian dan Pemasaran yaitu Lenses theory 102 yaitu dokumentasi, selama masa pengembangan game peneliti membuat dokumentasi dalam pengembangannya, yaitu dokumentasi saat pengujian oleh ahli sampai respon pengguna. Lenses theory 103 yaitu pengujian, peneliti melakukan 2 pengujian yaitu uji whitebox dan uji blackbok, peneliti juga sudah menentukan siapa saja yang terlibat dalam pengujian tersebut.Lenses theory 108 yaitu pemasaran, game dibuka guna untuk sebagai salah satu sarana untuk mengenalkan dan melestarikan permainantradisional, peneliti melakukan uji kelayakan pada game dan mendapatkan hasil yang sangat memuaskan sehingga peneliti yakin bahwa game akan berhasil dalam pemasarannya.Lenses theory 113 yaitu tujuan rahasia, peneliti sudah menentukan tujuan utama dari pengembangan game ini yaitu membuat game menjadi salahsatu saran pengenalan dan pelestari permainan tradisional khususnya permainan tradisional megala-gala.

Dari penerapan lenses theory pada tahap initiation didapatkan yaitu kebutuhan perangkat lunak, tujuan perangkat lunak, masukan dan keluaran perangkat lunak.

Tahap kedua adalah pre-production, pada tahap ini dirancang Game Design dan Prototype meliputi Game Description, Game Leveling, Game Rules, Victory Condition, Lost Condition. Pada tahap ini dilakukan perancangan perangkat lunak, model perangcangan perangkat lunak menggunakan model use case diagram dan aktivity diagram. Pada tahap ini juga dilakukan pembatasan dalam perancangan perangkat lunak, kemudian dari use case dan aktivity diagram didapatkan perancangan struktur navigasi perangkat lunak. Perancangan desain karakter dan antarmuka perangkat lunak juga dirancangan pada tahap ini.

Tahap ketiga adalah production, tahap inti yang berkisar pada penciptaan asset, pembuatan source code dan integrasi kedua elemen tersebut. Dalam tahap pre-production, sebelumnya telah disusun kerangka game. Dalam tahap production ini, kerangka yang masih konseptual tersebut direalisasikan menjadi produk yang siap ditesting.

Tahap keempat adalah testing, tahap dimana aplikasi telah siap untuk diperkenalkan dan dilakukan pengujian kelayakan. Pengujian dalam konteks ini berarti pengujian internal untuk menguji usability dan playability. Pengujian yang dilakukan dengan Uji Whitebox. Pengujian ini dilakukan oleh peneliti, penilaian pengujian berdasarkan kebenaran proses dari source code aplikasi sudah sesuai dengan fungsinya dan dapat berjalan dengan baik.

Tahap kelima adalah beta, tahap dimana aplikasi dilakukan pengujian pihak ketiga atau eksternal. Pengujian beta menggunakan pengujian blackbox, karena prototipe terkait dalam pengujian beta adalah rincian formal dan penyempurnaan. Pengujian blackbox pada tahap beta meliputi pengujian ahli media, ahli isi dan pengujian usability. Pada pengujian ahli media, peneliti melibatkan dua orang dosen Pendidikan Teknik Informatika dari Universitas Pendidikan Ganesha. Fokus penilaian pada pengujian ahli media adalah tampilan aplikasi yang meliputi pewarnaan, grafis, interaktif menu dan ikon, kemudian kualitas teknis yang meliputi pengoperasian aplikasi, keamanan aplikasi dan penanganan kesalahan aplikasi.

Pada pengujian ahli isi, pengujian ahli isi yang dilakukan melibatkan seseorang yang ahli dan mengerti mengenai permainan tradisional, penguji dalam game tradisional ini adalah bapak Made Taro, dimana beliau adalah sebagai salah satu tokoh pelestari permainan tradisional bali. Hasil dari pengujian ahli isi mendapatkan hasil yang positif dan beliau selaku tokoh pelestari permainan tradisional sangat antusias dan mendukung pelestarian permainan tradisional ini 
diperkenalkan melalui media digital contohnya melalui game android.

Pengujian terakhir adalah uji usability, penilaian pengujian dibagi menjadi 4 kasus uji yaitu pengujian uji kasus 1 : penggunaan aplikasi pada perangkat android yang berbeda, melibatkan 14 orang responden, uji kasus 2 : yaitu kebenaran proses aplikasi, melibatkan 14 orang responden, uji kasus 3 : tampilan, kualitas teknis dan leveling, melibatkan 50 orang responden dan uji kasus 4 yaitu kelayakan aplikasi sebagai game tradisional, pengujian ini melibatkan 50 orang responden. Berikut gambar grafik uji usabilitypada Gambar 24.

\section{Grafik Hasil Uji Usability}

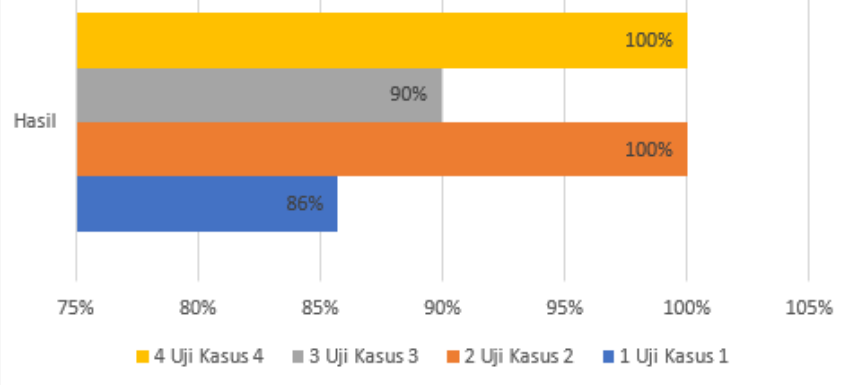

Gambar 24. GrafikHasilUji Usability

Berdasarkan grafik di atas diketahui bahwa pada pengujian uji kasus 1 didapatkan hasil rata-rata nilai $86 \%$ dengan kategori persentase sangat sesuai, dimana pada penilaian kesesuaian layar pada perangkat android yang mempunyai ratio layar 18:9 dan 19:9 masih belum maksimal pada mode tampilan layarnya. Pada uji kasus 2 didapatkan rata-rata nilai $100 \%$ dengan kategori persentase sangat sesuai yaitu dimana semua perangkat android yang digunakan dalam kebenaran proses aplikasi sudah berjalan sesuai dengan fungsinya. Selanjutnya, pada pengujian uji kasus 3 didapatkan rata-rata nilai $90 \%$ dengan kategori persentase sangat sesuai yang artinya pada segi tampilan, kualitas teknis dan leveling sudah mendapatkan hasil yang memuaskan. Terakhir adalah uji kasus 4 dengan rata-rata nilai $100 \%$ dengan kategori persentase sangat sesuai yang artinya seluruh responden mengakui dan setuju bahwa game ini layak digunakan sebagai salah satu sarana pengenalan dan pelestarian permainan tradisional megala-gala.

Tahap keenam adalah release, tahap akhir dari metode GDLC, produk game yang dibuat sudah dalam bentuk .apk dan sudah siap untuk disebarluaskan ke kalangan umum. Pada tahap ini dilakukan pembuatan dokumentasi dari game mulai dari cara memasang game sampai dengan cara penggunaan game.

Pengembangan game tradisional megala-gala berbasis android ini telah berbasil dikembangkan dan dilakukan serangkaian pengujian kelayakan, baik internal maupun eksternal atau dalam penelitian ini disebut pengujian whitebox dan blackbox. Selama pengembangannya ada beberapa kendala yang dihadapi oleh peneliti yaitu peneliti mengalami kendala dalam pembuatan AI (Artificial Intelligence) baik dari pemain dan penjaga serta bantuan dan rintangan tambahan dalam game. Kemudian terdapat kendala pada perangkat yang digunakan pada pengujian, yaitu penguji hanya menggunakan 1 perangkat android sehingga menyebabkan source code penyesuaian tampilan layar pada ratio yang berbeda tidak maksimal.

Berdasarkan hasil dari penelitian pengembangan game tradisional megala-gala dengan penelitian terkait didapatkan hasil bahwa metode GDLC (Game Development Life Cycle) sangat cocok digunakan dalam pengembangan game karena tahapan-tahapan dari metode tersebut sangat sesuai dengan karakteristik dari pengembangan game. Penggunaan lenses theory dalam mengembangan game dirasa sangat bermanfaat karena dapat memetakan pengembangan dengan maksimal mulai dari tahap awal menentukan ide, perancangan game sampai dengan pengujian dan pemasaran game. Hasil dari penerapan metode GDLC dan lenses theory menghasilkan game tradisional megala-gala dengan kategori persentase nilai sangat baik atau sangat sesuai.

\section{SIMPULAN}

Berdasarkan hasil dari penerapan metode GDLC pada penelitian Pengembangan Game Tradisional Megala-gala berbasis android dapat ditarik kesimpulan sebagai berikut.

1. Pengembangan Game Tradisional Megala-gala membutuhkan perangkat lunak maupun perangkat keras dalam pengembangannya. Perangkat lunak utama dalam pengembangan ini adalah Unity, yaitu untuk pembuatan game android dan pengolahan soure code dari game tersebut. Sedangkan perangkat keras utama dalam pengembangan ini adalah laptop untuk sarana pengembangan game dan perangkat berbasis android untuk mengimplementasikan game. Dalam pengembangan game ini diimplementasikan pada beberapa tipe perangkat android yang berbeda, dimana dari hasil pengujian didapatkan bahwa tidak semua tipe perangkat android dalam hal kesesuaian layar menyesuaikan dengan perangkat yang digunakan namun dalam hal kebenaran proses semua tipe android yang digunakan sudah berjalan dengan baik sebagaimana fungsinya.

2. Hasil implementasi dari Pengembangan Game Tradisional Megala-gala mendapatkan nilai yang sangat baik, dimana dalam pengujian usability oleh respon pengguna didapatkan hasil dalam uji kasus 3 : tampilan, kualitas teknis dan leveling mendapatkan nilai rata-rata $90 \%$ dengan kategori persentase sangat sesuai dan uji kasus 4 : kelayakan aplikasi sebagai game tradisional mendapatkan nilai rata-rata $100 \%$ dengan kategori persentase sangat sesuai. Dari hasil respon pengguna tersebut bisa dikatakan 
pengembangan game tradisional megala-gala berbasis android guna untuk mengenalkan dan melestarikan permainan tradisional megala-gala ini sudah berhasil terlepas dari permasalahan-permasalahan yang ada.

\section{REFERENSI}

[1] S. Widyosismoyo, Ilmu Budaya Dasar, Bogor: Ghalia Indonesia, 2004.

[2] I. M. Taro, Interviewee, Permainan Tradisional "Megala-gala". [Wawancara]. 14072017.

[3] K. F. Mauladi dan M. Sholihin, "Game Gobak Sodor Berbasis Android," JOUTICA-PRESS, pp. http://journal.unisla.ac.id/pdf/112112016/Jurnal\%20Gob ak\%20Sodor\%20Kemal-Miftahus.pdf, 2016.

[4] B. D. C. Putri, R. Kridalukmana dan E. D. Widianto, "Perancangan Aplikasi Permainan Multiplayer Gobak Sodor Berbasis Flash di Lingkup Jaringan Lokal," Jurnal Teknologi dan Sistem Komputer, p.

http://jtsiskom.undip.ac.id/index.php/jtsiskom/article/vie w/12711, 2016.

[5] I. G. W. Antara, I. G. M. Darmawiguna dan I. M. G. Sunarya, "Pengembangan Game Jegog Berbasis Android," Janapati, p. http://ejournal.undiksha.ac.id/index.php/janapati/article/v iew/9774, 2015.

[6] I. K. D. Permana, I. M. A. Wirawan dan I. K. R. Arthana, "PENGEMBANGAN GAME EDUKASI SIAP SELEM BERBASIS ANDROID," Karmapati, p. http://ejournal.undiksha.ac.id/index.php/KP/article/view/ $6522,2015$.

[7] C. Crawford, The Art of Computer Game Design, Washington: Osborne McGraw-Hill, 1984.

[8] J. Schell, The Art of Game Design A Book of Lenses Second Edition, New York: CRC Press, 2015.

[9] I. H. Misbach, Peran permainan tradisional yang bermuatan edukatif dalam menyumbang pembentukan karakter dan identitas bangsa, Bandung, 2006.

[10] Bewish, "Megala-gala - Balinese Team Bonding," 3009 2015. [Online]. Available:

https://balicultureinformation.wordpress.com/2015/09/30 /megala-gala-balinese-team-bonding/.

[11] S. Kendal, Object Oriented Programming Using C\#, bookboon.com: Bookboon.com, 2011.

[12] K. E. K. \&. J. E. Kendall, System Analysis And Design, New Jersey: Prentice Hall, 2011.

[13] R. Ramadan dan Y. Widnyani, "Game Development Life Cycle Guidelines," ICACSIS, p. https://www.researchgate.net/publication/271548605_Ga me_development_life_cycle_guidelines, 2013

[14] R. M. Y. d. Aristiawan, "Unity 3D - Game Engine," 37 2015. [Online]. Available:

http://www.hermantolle.com/class/docs/unity-3d-gameengine/.

[15] H. Gould, Systems Analysis and Design, bookboon.com: Bookboon.com, 2016.

[16] P. Roger S. Pressman, Software Engineering : A PRACTITIONER'S APPROACH, Boston: McGrawHill, 2001.

[17] J. Schell, The Art of Game Design, Burlington: Morgan Kaufmann, 2008.

[18] D. Moursund, "Introduction to Using Games in Education," A Guide of Teacher, p. 27, 15 Agustus 2006.

[19] K. Dyrr, P. F. Navarro, R. Oliveira dan B. Sparks, Game Development for Human Beings, Australia: Zenpa, 2016.

[20] B. Simamora, Analisis Multivariat Pemasaran, Jakarta: PT Gramedia Pustaka Utama, 2005.

[21] M. Yumarlin, "Pengembangan Permainan Ular Tangga Untuk Kuis Mata Pelajaran Sains Sekolah Dasar," Jurnal Teknik, pp. http://jurnalteknik.janabadra.ac.id/wpcontent/uploads/2014/03/10-Revisi-YUMARLIN-22-813.pdf, 2013.

[22] A. D. Wulandari, "Game Edukatif Sejarah Komputer Menggunakan Role Playing Game (RPG) Maker XP sebagai Media Pembelajaran di SMP Negeri 2 Kalibawang," p. http://eprints.uny.ac.id/7549/, 2012.

[23] M. Siagawati, W. D. Pratiti dan Purwati, "MENGUNGKAP NILAI-NILAI YANG TERKANDUNG DALAM PERMAINAN TRADISIONAL GOBAG SODOR,” Indigenous, Jurnal Ilmiah Berkala Psikologi, p.

https://publikasiilmiah.ums.ac.id/bitstream/handle/11617 /1406/6Monica_Vol\%209\%20No\%201\%20Mei\%20200 7.pdf? sequence=1\&isAllowed=y, 2007. 